\title{
Rolnictwo czy węgiel brunatny - utylitarność zasobów w rozwoju lokalnym gminy Krobi
}

\section{Agriculture or brown coal: usability of resources in the local development of Krobia commune}

\author{
Anna KOŁODZIEJCZAK \\ Uniwersytet im. Adama Mickiewicza w Poznaniu \\ Instytut Geografii Społeczno-Ekonomiczneji Gospodarki Przestrzennej \\ ul. Bogumiła Krygowskiego 10, 61-680 Poznań \\ aniaka@amu.edu.pl
}

Zarys treści: W artykule przedstawiono koncepcję zakorzenienia, która jest nowym spojrzeniem na możliwość rozwoju lokalnego obszarów wiejskich w oparciu o występujące tam zasoby endogenne oraz mechanizm stymulowania społeczności. W tym kontekście pokazano warunki i zasoby typowo rolniczej gminy Krobi położonej w południowo-zachodniej części województwa wielkopolskiego, które przyczyniają się do jej rozwoju lokalnego i regionalnego. Poza tym gmina Krobia zaliczana jest do obszarów perspektywicznych występowania udokumentowanych pokładów węgla brunatnego (złoże Poniec-Krobia). Wskazać należy na brak społecznej akceptacji dla wizji wydobycia węgla brunatnego. Powstanie na tym terenie kopalni odkrywkowej niesie za sobą wiele negatywnych skutków dla bardzo dobrze rozwiniętego rolnictwa, a w konsekwencji dla społeczności lokalnej. W artykule wskazano sposoby wzmocnienia „zakorzenienia”, aby w maksymalnym stopniu wartość dodana z działalności mieszkańców (rolniczej i pozarolniczej), przy efektywnym wykorzystaniu endogenicznych zasobów, pozostała na obszarze tej gminy i służyła dalszemu rozwojowi lokalnemu.

Słowa kluczowe: koncepcja zakorzenienia, utylitarność zasobów, rozwój lokalny, gmina Krobia.

\section{Wstęp}

Podstawą rozwoju określonego obszaru są zasoby lokalne, które mogą mieć charakter materialny (surowce, produkty, walory środowiskowe itp.) i niematerialny (relacje, umiejętności i zdolności mieszkańców, powiązania, kultura itp.). Zasoby i dobra są na ogół mocno związane ze specyfiką regionu, są czymś wyjątkowym, tworząc możliwości dla aktywności mieszkańców. Są to czynniki o różnorodnym sposobie oddziaływania na rozwój lokalny. Na ogół jednemu z nich nadaje się wysoką wartość, która może być wynikiem naturalnych lub stymulowanych zewnętrznie procesów. Dostrzeżenie odmienności i nadanie wartości temu co rzadkie, specyficzne i lokalne jest odejściem od paradygmatu rozwoju zakładającego masowość i jednolitość produkcji. Rozwój lokalny opiera się na przestrzennej formie koncepcji zakorzenienia, która oznacza związanie podmiotów z określonym obszarem 
i procesami w nim zachodzącymi. Według K. Stachowiaka (2011, s. 89) łączy ono w sobie elementy innych form zakorzenienia - kulturowego, politycznego czy instytucjonalnego, które są ograniczone do konkretnego terytorium. Z. Chojnicki (1999, s. 318) określa terytorium, jako „obszar powierzchni Ziemi wraz z jego zawartością materialną, naturalną i sztuczną, efektywnie kontrolowaną przez zbiorowość ludzi”. W rzeczywistości wszystkie te formy zakorzenienia są związane ze sobą i rzadko występują osobno, co wynika ze złożoności i wielowymiarowości życia społecznego. Dzięki koncepcji zakorzenienia wartość, jaką stanowi lokalność oraz jakość zasobów cenione są także poza obszarem występowania i dostępne są na większą skalę, często poza miejscem produkcji.

Rozwój na podstawie koncepcji zakorzenienia ma miejsce w gminie Krobia, gdzie zasoby lokalne, tradycja dobrego gospodarowania oraz zachowana wysoka kultura rolna powodują, że jest ona jednym z liderów w zakresie produkcji żywności wysokiej jakości w skali województwa wielkopolskiego i kraju. Oprócz intensywnego rolnictwa na terenie gminy występują udokumentowane złoża węgla brunatnego (Krobia-Oczkowice), które przyczyniły się do zamiaru powstania w przyszłości kopalni odkrywkowej.

Celem badań jest odpowiedź na pytanie: rolnictwo czy węgiel brunatny decydować będzie o dalszym rozwoju lokalnym gminy Krobia?

\section{Koncepcja zakorzenienia a rozwój lokalny}

Koncepcja zakorzenienia posiada różnorodność ujęć i dowolność interpretacji, co utrudnia wykorzystanie w badaniach empirycznych. Pojęcie zakorzenienia niezbyt precyzyjnie zdefiniowane w literaturze pochodzi od antropologa społecznego K. Polanyi'ego (1944). Uważał on, że gospodarka nie jest autonomiczna, jak wynikało z klasycznych teorii ekonomicznych, lecz podlega relacjom społecznym lub polityce. Dla Polanyi'ego zakorzenienie oznacza zależność między zachowaniami gospodarczymi a stosunkami społecznymi. Pojęciem zakorzenienia zajął się ponownie M. Granovetter (1985), który uważał, że podmioty gospodarcze nie podejmują decyzji niezależnie od kontekstu społecznego, a ich celowe działanie jest za to zakorzenione w konkretnych, funkcjonujących aktualnie systemach relacji społecznych. Istotną rolę odgrywają sieci powiązań i złożone relacje, jakie zachodzą pomiędzy uczestnikami procesów ekonomicznych. To w nich jednostki i firmy oraz ich zachowania gospodarcze są zakorzenione.

Koncepcja zakorzenienia została zaadoptowana do specyfiki badań przestrzenno-ekonomicznych. Przez zakorzenienie rozumie się umocowanie różnych podmiotów w określonym środowisku bądź otoczeniu, a także w strukturze regionalnej lub w lokalnych praktykach (Grzeszczak 1999, s. 57). Koncepcja zakorzenienia odwołuje się do wykorzystania lokalnych zasobów w celu rozwoju danego obszaru zarówno w wymiarze gospodarczym, społecznym, jest ona efektem zmian w myśleniu o funkcjach i celach rozwoju obszaru wiejskiego. Zakorzenienie powiązane jest z ideą zrównoważonego rozwoju, która zdaniem T. Adamskiego i K. Gorlacha (2007, s. 142) wskazuje „na konieczność przyjęcia takiej strategii przeobrażeń, która nie niszczy zlokalizowanych na określonym obszarze przyrodniczych, gospodarczych i społecznych zasobów, umożliwiając tym samym kontynuowanie rozwoju w przyszłości." Za rozwój zrównoważony jest odpowiedzialny neoendogenny mechanizm rozwojowy, który zakłada, że obok powszechnej partycypacji aktorów lokalnych, konieczne jest zaangażowanie aktorów ponadlokalnych, 
tj. władz regionalnych, działających na szerszą skalę organizacji pozarządowych, a nawet rządu.

Za sprawą koncepcji zakorzenienia powstaje swoisty gospodarczo-społeczny system wzajemnych zależności, który przez odpowiednie zarządzanie (sformalizowane lub niesformalizowane) zasobami w maksymalny sposób pozwala zachować zyski i korzyści z nich płynące na danym obszarze z użytecznością dla lokalnej społeczności i rozwoju. Należy podkreślić, że rozwój lokalny wynika z określonych uwarunkowań społecznych i gospodarczych oraz zawsze jest zakorzeniony w konkretnym otoczeniu instytucjonalnym. W jego kształtowaniu często niebagatelne znaczenie mają samorządy lokalne, mogą uczestniczyć różne organizacje, tj. lokalne grupy działania, miejscowe izby gospodarcze, zrzeszenia rolnicze, spółdzielnie czy nawet parafie. Podstawą modelu rozwoju lokalnego w oparciu o koncepcję zakorzenienia jest ujmowanie procesów gospodarczych (produkcji, dystrybucji, konsumpcji) w kategoriach działań połączonych ze sobą przez wykorzystanie zasobów lokalnych oraz przepływy dóbr zarówno materialnych, jak i niematerialnych (usług), które odbywają się na określonym obszarze (ryc. 1).

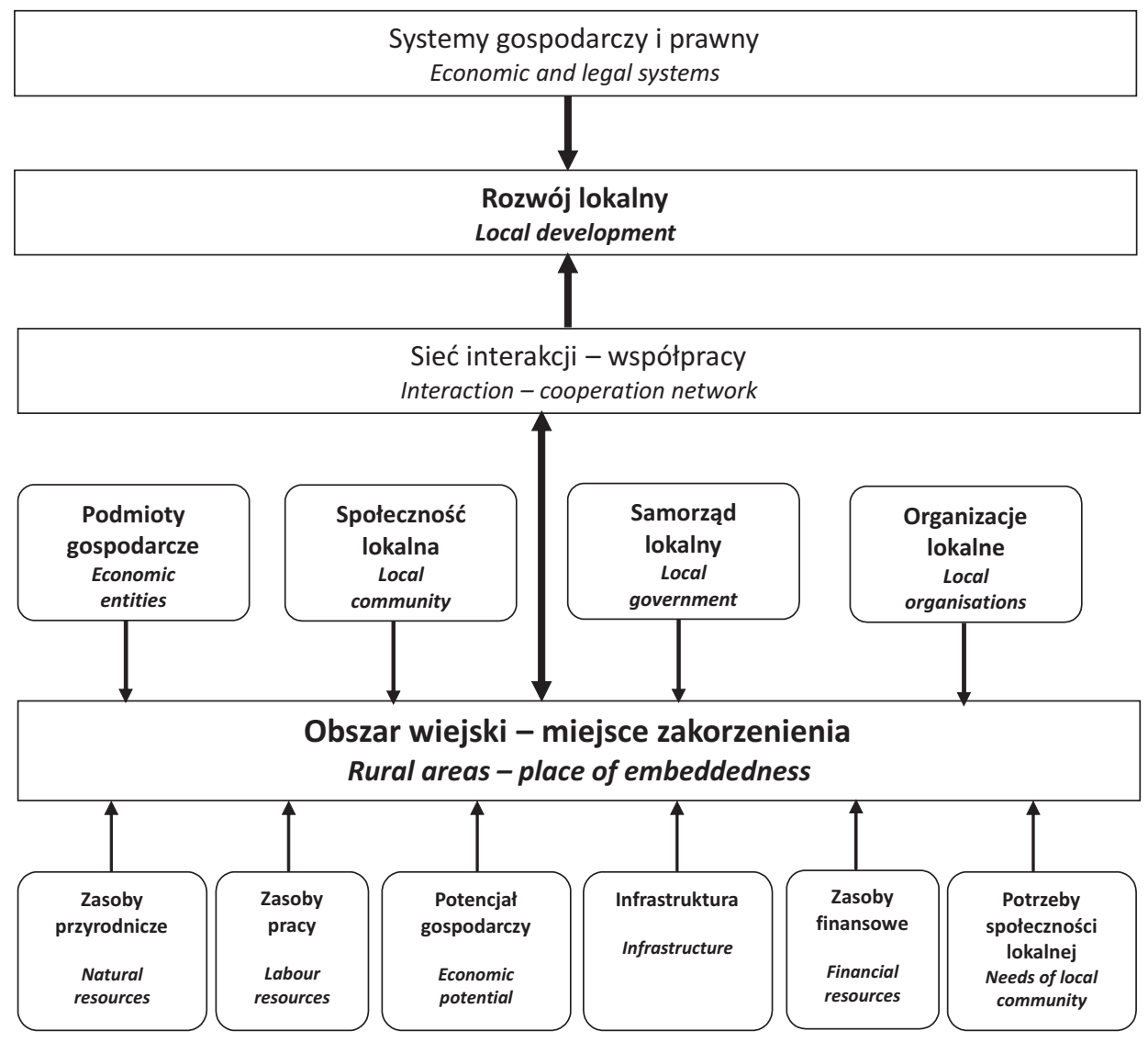

Ryc. 1. Model rozwoju lokalnego na podstawie koncepcji zakorzenienia Model of local development based on the concept of embeddedness Źródło/Source: opracowanie własne/own compilation. 
Istotne jest nadanie wartości szczególnego rodzaju zasobu (krajobrazu, aktywności, umiejętności mieszkańców) przypisanego ściśle do obszaru, na którym występuje. Tak wyróżniony zasób staje się przyczyną do tworzenia procesów, w których relacje pomiędzy aktorami - podmiotami gospodarczymi, społecznością lokalną, samorządem oraz organizacjami lokalnymi są zróżnicowane. W ramach tych zróżnicowanych mikrostruktur działania i relacje pomiędzy uczestnikami kształtują charakter lokalnej gospodarki, a sieci interakcji są modyfikowane przez relacje władzy. Zdaniem P. Dickena (2004) najważniejszymi czynnikami wpływającymi na względną władzę uczestników, a przez to na rozwój lokalny są: kontrola nad posiadanymi zasobami lokalnymi i przestrzenny zakres działania.

Można stwierdzić, że ideą koncepcji zakorzenienia jest wykorzystanie posiadanych zasobów o ściśle lokalnym, endogennym charakterze, oparte na współpracy i współdziałaniu mieszkańców, oferujących swoje produkty i usługi na rynku. Wówczas wartość dodana z działalności mieszkańców w możliwie dużym stopniu pozostanie na danym obszarze i będzie służyła rozwojowi lokalnemu (Jasiński i in. 2014).

\section{Uwarunkowania rozwoju lokalnego gminy Krobi}

Krobia jest gminą miejsko-wiejską położoną w województwie wielkopolskim, około $80 \mathrm{~km}$ na południe od Poznania. Wchodzi ona wraz z 6 gminami (Borek Wielkopolski, Gostyń, Pogorzela, Poniec, Pępowo i Piaski) w skład powiatu gostyńskiego. Gmina Krobia graniczy od północy z gminami: Gostyń i Piaski, od wschodu z Pępowem, od południa z Miejską Górką, a od zachodu z Poniecem. Przez środek gminy przebiega droga powiatowa nr 434 Kórnik-Rawicz.

Obszar gminy wynosi 130 km², co stanowi 15,99\% powierzchni powiatu gostyńskiego (3 miejsce wśród 7 gmin), a zarazem 0,43\% województwa wielkopolskiego (97 miejsce wśród 226 gmin).

Według fizycznogeograficznej regionalizacji Polski J. Kondrackiego (2002) teren gminy leży na obszarze makroregionu Niziny Południowowielkopolskiej (318.1-2), a w jej obrębie w mezoregionie Wysoczyzny Leszczyńskiej (318.11) i mezoregionie Wysoczyzny Kaliskiej (318.12). Granica pomiędzy tymi dwiema jednostkami przebiega wschodnim obrzeżem doliny Rowu Polskiego. Większa część terytorium gminy położona jest na Wysoczyźnie Kaliskiej. Gmina Krobia zaliczana jest do obszarów perspektywicznych występowania pokładów węgli brunatnych. Ich zasoby zostały tu jednak udokumentowane jedynie szacunkowo (złoże Poniec-Krobia). Sumaryczna miąższość warstw węgla wynosi średnio 20,8 m, a pokładów bilansowych 14,7 m. Zalegają one na głębokości 100-200 m (Kasztelewicz i in. 2012).

Gmina Krobia jest zasobna w wody powierzchniowe, na które składa się gęsta sieć rzek i rowów melioracyjnych łączących Kanię z Rowem Polskim. Większa część gminy należy do dorzecza Baryczy, natomiast fragment północnego i północno-zachodniego terytorium do dorzecza Warty. Niemal cała powierzchnia gminy ma wiele urządzeń meliorujących. W podmakających dnach dolin są to rowy melioracyjne, natomiast na obszarze wysoczyzny urządzenia drenarskie. Sieć rowów melioracyjnych odwadnia strefy podmokłości stałych i okresowych. Jest ona stale zmieniana. Sieć cieków melioracji podstawowych terenu gminy obejmuje: Rów Krobski (na długości 7,28km), Rów Polski (7,35km), Samicę Krobską $(17,23 \mathrm{~km})$, Dąbrocznię $(4,5 \mathrm{~km})$, Rów Rogowski (3,5km) i Masłówkę (4,1km). Z cieków 
tych odcinki uregulowane posiada Rów Polski i Samica Krobska. Cieki melioracji podstawowych terenu gminy nie posiadają obwałowań (Studium Uwarunkowań... 2011).

Gmina Krobia zasobna jest w urodzajne gleby klas II i III (74\% powierzchni gruntów ornych), zaliczane do kompleksu pszennego bardzo dobrego i dobrego (tab. 1). Najbardziej urodzajne gleby (brunatne właściwe i wyługowane oraz bielicoziemne) występują w okolicach Krobii, Domachowa i Wymysłowa. Kompleks pszenny wadliwy występuje wąskim pasami na obu zboczach doliny Rowu Polskiego, w okolicach Bukowicy, Starej Krobi i Żychlewa.

Tabela 1. Struktura gruntów ornych wg klas bonitacyjnych w gminie Krobia i powiecie gostyńskim na tle województwa wielkopolskiego

\begin{tabular}{|l|c|c|c|c|c|c|c|}
\hline \multirow{2}{*}{\multicolumn{1}{c|}{ Wyszczególnienie }} & \multicolumn{7}{|c|}{ Grunty orne wg klas bonitacyjnych w \% } \\
\cline { 2 - 8 } & II & IIla & IIIb & IVa & IVb & V & VI \\
\hline Gmina Krobia & $\mathbf{5}$ & $\mathbf{5 0}$ & $\mathbf{1 9}$ & $\mathbf{1 6}$ & $\mathbf{5}$ & $\mathbf{4}$ & $\mathbf{1}$ \\
Powiat gostyński & 3 & 47 & 18 & 16 & 5 & 8 & 3 \\
Województwo wielkopolskie & 1 & 12 & 12 & 24 & 11 & 22 & 18 \\
\hline
\end{tabular}

Źródło: Agrochemiczne badania gleb Wielkopolski w latach 2000-2004 (2005).

Kompleksy żytnie: bardzo dobry i dobry wykształciły się na glebach pseudobielicowych powstałych z piasków gliniastych lekkich na podłożu glin i występują na dużych obszarach w okolicach Żychlewa i Starej Krobi oraz na południe od Przyborowa. Kompleks żytni bardzo słaby występuje na obrzeżu powierzchni zalesionej na południowy zachód od Karca.

Na dnie dolin występują gleby aluwialne (mady), bagienne (gleby mułowo-torfowe) i pobagienne (gleby murszowe). Tereny te zajęte są głównie pod łąki i pastwiska. Korzystne warunki glebowe przyczyniają się do tego, że gmina należy do tych obszarów województwa wielkopolskiego, na których rozwinięta jest gospodarka rolna o wysokim poziomie. W 2013 r. użytki rolne miały największy udział w powierzchni ogółem (90,3\%), następnie tereny zabudowane (5,3\%) oraz lasy i zadrzewienia (4,2\%). Gmina wyróżnia się korzystnymi warunkami agro-klimatycznymi: występuje tutaj niewielka liczba dni z przymrozkami (78 dni), najdłużej trwający w województwie wielkopolskim okres wegetacyjny - 228 dni oraz najwyższa w porównaniu z pozostałymi rejonami Wielkopolski wysokość opadów w okresie wegetacyjnym - 374 mm (Południowy Obszar Intensywnego Rolnictwa 2014). Wskaźnik rolniczej przestrzeni produkcyjnej dla gminy Krobia wynosi 91,6 pkt i jest najwyższy w skali województwa wielkopolskiego, który stanowi 63,4 pkt (Waloryzacja... 2007). Wskazuje on na duże możliwości tkwiące w warunkach przyrodniczych dla rozwoju rolnictwa w badanej gminie.

Sieć osadniczą tworzą miasto Krobia i 22 sołectwa, rozproszone równomiernie na terenie gminy (ryc. 2). Wsie są zróżnicowane pod względem ludności. Przeważają małe wsie od 70 do 455 osób, natomiast dużą wieś stanowią Pudliszki, które w 2011 r. liczyły 2356 mieszkańców (tab. 2). W 2014 r. w gminie mieszkało 13032 osób, z czego 4236 w mieście. W gminie Krobia wykształcił się „dwubiegunowy” układ funkcjonalny, który zdominował sieć osadniczą miasta i obszarów wiejskich.

Miasto Krobia jest ośrodkiem usługowym, a Pudliszki to miejsce pracy. W pozostałych miejscowościach występuje zdecydowana przewaga funkcji rolniczych, które zamykają się w granicach sołectw. W 2014 r. w rolnictwie pracowało 33,6\% osób, natomiast w przemy- 
śle 35,9\% ogółu pracujących. Współczynnik bezrobocia był na średnim poziomie i wynosił 9,6\%. W 2014 r. potencjał gospodarczy gminy stanowiło 1189 gospodarstw rolnych oraz 1077 podmiotów gospodarczych, których najwięcej jest w handlu, budownictwie, branży drzewnej oraz produkcji bryczek i powozów konnych. Największy zakład to HJ Heinz Polska SA w Pudliszkach, który produkuje koncentrat pomidorowy, ketchupy, nowoczesne i tradycyjne dania gotowe, a także warzywa w puszkach oraz sałatki warzywne. Przez gminę przebiegają drogi wojewódzkie, powiatowe i gminne oraz linia kolejowa Głogów - Ostrów Wielkopolski ze stacją w Krobi. Gmina posiada dobrze rozwiniętą sieć wodociągową, natomiast słabo sieć kanalizacyjną. Wg danych GUS w 2015 r. na 100 km² powierzchni gminy przypadało 87,6 km sieci wodociągowej, z której korzystało 94\% mieszkańców (przy średniej dla województwa wielkopolskiego 92\%), natomiast wskaźnik gęstości sieci kanalizacyjnej wynosił 13,7 km/ $\mathrm{km}^{2}$ i była ona dostępna dla 33\% mieszkańców (przy średniej dla województwa 92\%).

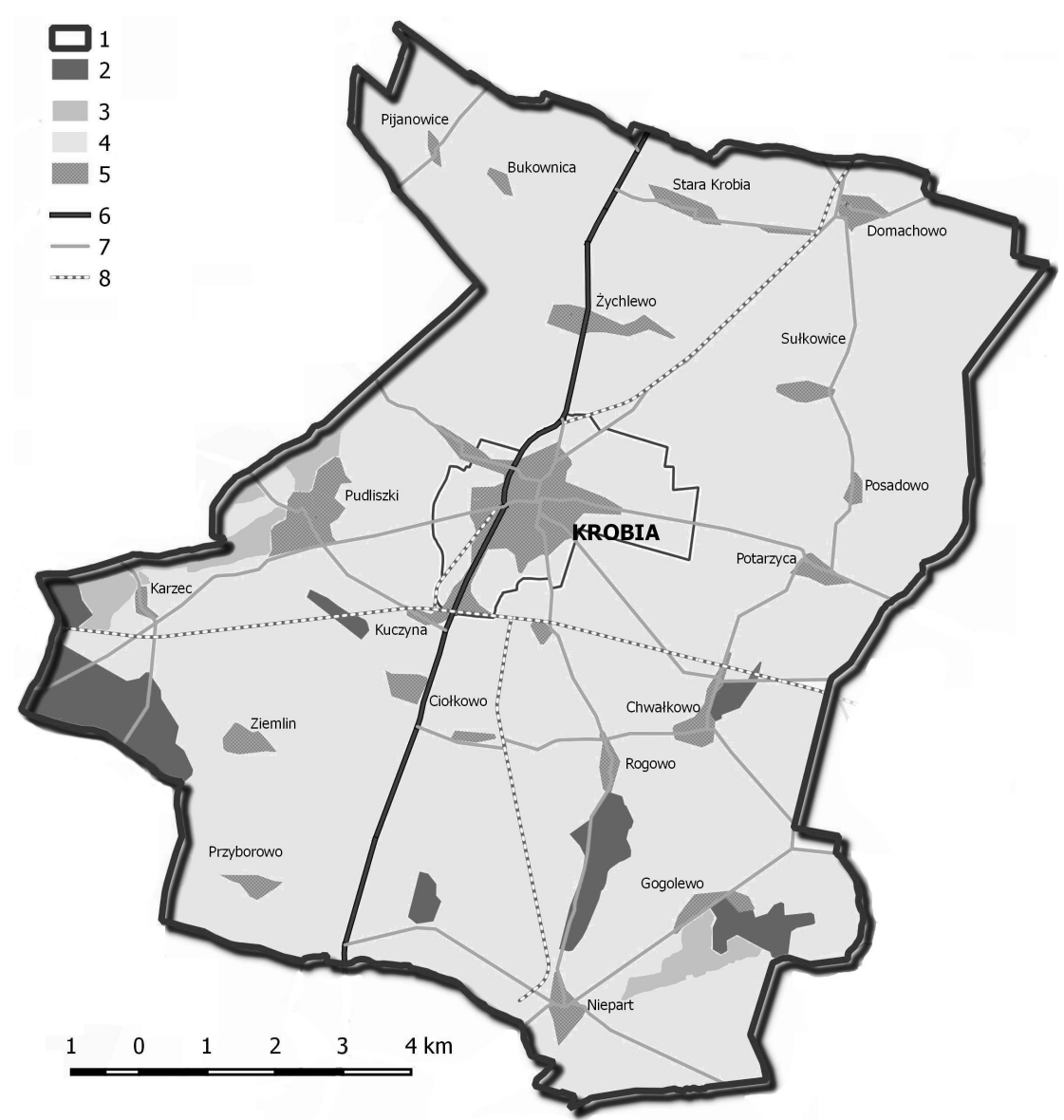

Ryc. 2. Użytkowanie ziemi w gminie Krobia: 1 - granica gminy, 2 - lasy, 3 - łąki i pastwiska, 4 - grunty orne, 5 - miejscowości, 6 -drogi główne, 7 -drogi drugorzędne, 8 - linie kolejowe.

Land use pattern in Krobia commune: 1 -commune boundary, 2 -woodland, 3 - meadows and pastures, 4 - arable land, 5 - localities, 6 - main roads, 7 - secondary roads, 8 - railway lines.

Źródło /Source: L. Kaczmarek (2016). 
Tabela 2. Klasyfikacja wielkościowa wsi w gminie Krobia w 2011 r.

\begin{tabular}{|l|c|l|c|c|c|}
\hline \multicolumn{1}{|c|}{ Wsie małe } & \multicolumn{2}{c|}{ Wsie średnie } & \multicolumn{2}{c|}{ Wsie duże } \\
\hline \multicolumn{1}{|c|}{ Nazwa } & $\begin{array}{c}\text { Liczba } \\
\text { ludności }\end{array}$ & \multicolumn{1}{|c|}{ Nazwa } & $\begin{array}{c}\text { Liczba } \\
\text { ludności }\end{array}$ & Nazwa & $\begin{array}{c}\text { Liczba } \\
\text { ludności }\end{array}$ \\
\hline Krabianowo & 70 & Stara Krobia & 506 & Pudliszki & \\
Przyborowo & 89 & Niepart & 509 & & \\
Wymysłowo & 130 & Gogolewo & 606 & \\
Pijanowice & 160 & Sułkowice & 631 & \\
Karzec & 168 & Chwałkowo & & \\
Ziemlin & 206 & & & \\
Rogowo & 221 & & & \\
Chumiętki & 229 & & & \\
Ciołkowo & 256 & & & \\
Posadowo & 256 & & & \\
Potarzyca & 262 & & & \\
Bukownica & 291 & & & \\
Kuczyna & 304 & & & \\
Żychlewo & 323 & & & \\
Domachowo & 400 & & & & \\
\hline
\end{tabular}

Źródło: opracowano na podstawie: Narodowy Spis Powszechny Ludności i Mieszkań 2011.

Gmina wchodzi w skład Lokalnej Grupy Działania „Gościnna Wielkopolska”. Przez teren gminy przebiega Ziemiański Szlak Rowerowy stworzony przez Międzygminny Związek Turystyczny „Wielkopolska Gościnna”.

Gmina Krobia przez wiele wieków była domeną biskupów poznańskich. Urodzajne gleby stanowiły o zasobności gospodarzy. Te tradycje do dziś wywierają wpływ na kulturę, wykształcenie, pracowitość i odpowiedzialność obywatelską mieszkańców tych ziem, którzy identyfikują się z historyczną częścią Wielkopolski nazywaną Biskupizną i chętnie przystają na nazwę Biskupian. Utworzono Biskupiański Szlak Turystyczny, który liczy 38 km i przebiega przez 13 miejscowości leżących na terenie gmin Krobia, Piaski i Gostyń. Z tym szlakiem powiązany jest Biskupiański Szlak Kulinarny oraz regionalna publikacja A. Kuźmińskiego (2012), która powstała przy udziale wielu mieszkańców i jest zbiorem przepisów pokazujących dorobek kulinarny gminy Krobia oparty na tradycjach i kulturze. Tradycje kulturowe Biskupizny zostały wpisane w dniu 5 grudnia 2016 r. na Krajową listę niematerialnego dziedzictwa kulturowego ${ }^{1}$.

\section{Rolnictwo a rozwój lokalny gminy}

Obok uwarunkowań przyrodniczych na wielkość produkcji duży wpływ mają czynniki społeczne i gospodarcze. One głównie wpłynęły na strukturę zasiewów, rozmiary i kierunki chowu zwierząt gospodarskich, poziom i kierunki produkcji towarowej na terenie południowym województwa wielkopolskiego. W gminie Krobia do sytuacji rynkowej przystosowała się większość indywidualnych gospodarstw rolnych. Zmiany w strukturze zasiewów wywołane głównie czynnikami społeczno-ekonomicznymi dotyczą wzrostu znaczenia zbóż, które stały się podstawowym komponentem zużywanych pasz. Podobnie

\footnotetext{
${ }^{1} \mathrm{http}: / /$ biskupizna.pl/asp/pl_start.asp? ref=1\&typ=13\&menu=9\&schemat=0\&dzialy=9\&akcja=artykul\&art ykul=196 [dostęp: 15.01.2017].
} 
jak w całym kraju, tak w gminie Krobia w strukturze zasiewów dominują zboża - przede wszystkim pszenica, mieszanki zbożowe, jęczmień oraz pszenżyto. Mniej wymagające zboża: żyto i owies zajmują niewielką część areału. Na obsiewanym obszarze 9136 ha w 2010 r., obejmującym 88,8\% gruntów ornych miasta i gminy, pszenica stanowiła 19,9\%, mieszanki zbożowe 16,4\%, jęczmień 13,5\% oraz pszenżyto 12,5\% areału. Niewielki udział w zasiewach mają ziemniaki i buraki cukrowe. Sytuacja gospodarcza spowodowała, że ważną rolę w strukturze zasiewów odgrywają warzywa gruntowe, a w szczególności pomidory. W 2010 r. pod uprawę warzyw przeznaczono 470 ha, co stanowiło 5,1\% powierzchni zasiewów, w tym pod pomidory 302 ha, tj. 3,3\% powierzchni zasiewów. Uprawy te mają tendencję wzrastającą, wiąże się to z dobrym zbytem i pewnością, jaką dają umowy kontraktacyjne zawierane przez rolników z zakładem przetwórstwa owocowo-warzywnego w Pudliszkach. Intensyfikacja produkcji roślinnej na obszarze gminy stanowi w dużej mierze bazę paszową dla prowadzonego tu chowu zwierząt gospodarskich. Głównym kierunkiem produkcji zwierzęcej jest chów trzody chlewnej. Bardzo wysoki wskaźnik obsady trzody chlewnej wynoszący 549 sztuk na 100 ha użytków rolnych w 2010 r. jest dwukrotnie wyższy od średniej wojewódzkiej - 240 sztuk na 100 ha użytków rolnych. Popularnym kierunkiem produkcji zwierzęcej jest chów bydła. Podobnie jak w przypadku trzody chlewnej w przeliczeniu na 100 ha użytków rolnych obsada bydła w 2010 r. wynosiła 57 sztuk i znacznie przewyższała poziom wojewódzki - 40 sztuk. Najważniejszym działem chowu bydła jest produkcja mleka, gdzie przeciętnie na tym obszarze uzyskuje się od krowy 8300 kg mleka na rok, przy średniej wojewódzkiej wynoszącej 7700 kg w 2010 r. Wysoka wydajność jest efektem systematycznie prowadzonych prac w chowie krów oraz dobrze rozwiniętego przetwórstwa mleka w sąsiedniej gminie Gostyń.

Bardzo dobre wyniki osiągane w produkcji rolnej są również rezultatem wysokiego zaangażowania środków produkcji. Znaczna część gospodarstw na terenie gminy została doinwestowana dzięki funduszom z Programu Rozwoju Obszarów Wiejskich 2007-2013. Potwierdza to dużą aktywność rolników powiatu gostyńskiego (gmina Krobia należy do tego powiatu) w pozyskiwaniu środków z działania Modernizacja gospodarstw rolnych PROW 2007-2013, gdyż umowę na dofinansowanie otrzymało 8,94\% (405) rolników działających w tym powiecie, podczas gdy w całym województwie wielkopolskim było to średnio o połowę mniej (4,93\% - 6107 rolników), a w Polsce takie umowy podpisało 3,6\% (57 029) rolników. Kwota wypłaconych środków w powiecie wynosiła 34,6 mln zł, co stanowiło łącznie 6,4\% środków wypłaconych w województwie (Poczta 2014).

\section{Złoża węgla brunatnego a rozwój lokalny gminy}

Złoża węgla brunatnego w okolicach między Rawiczem, Krobią i Skoraszewicami, w tym złoże Oczkowice zostały odkryte w latach 60. XX w. (Ciok 1963). Złoże Oczkowice o dokumentowanej powierzchni 71,04 km² stanowi jeden z zasobów lokalnych gminy (ryc. 3).

W granicach wyznaczonego obszaru złoża węgla brunatnego Oczkowice występują w jego nakładzie i otoczeniu bardzo cenne dla zaopatrzenia w wodę do picia i na potrzeby gospodarcze lokalne zbiorniki wód podziemnych w formie pasmowych struktur hydrogeologicznych z nagromadzeniem piasków i żwirów w obrębie czwartorzędowego piętra wodonośnego. W odległości 6,6 km od granic złoża węgla brunatnego Oczkowice znajduje się Główny Zbiornik Wód Podziemnych nr 308 o znaczeniu regionalnym - zbiornik 
międzymorenowy rzeki Kania o powierzchni 140 km² o strategicznych zasobach wód podziemnych dla bardzo deficytowego w zakresie zasobów wodnych powiatu gostyńskiego. Niemal cała powierzchnia w rejonie złoża Oczkowice ma wiele urządzeń meliorujących oraz kilkadziesiąt zbiorników małej retencji. W podmakających dnach dolin są to rowy melioracyjne, natomiast na obszarze wysoczyzny urządzenia drenarskie (Przybyłek 2015).

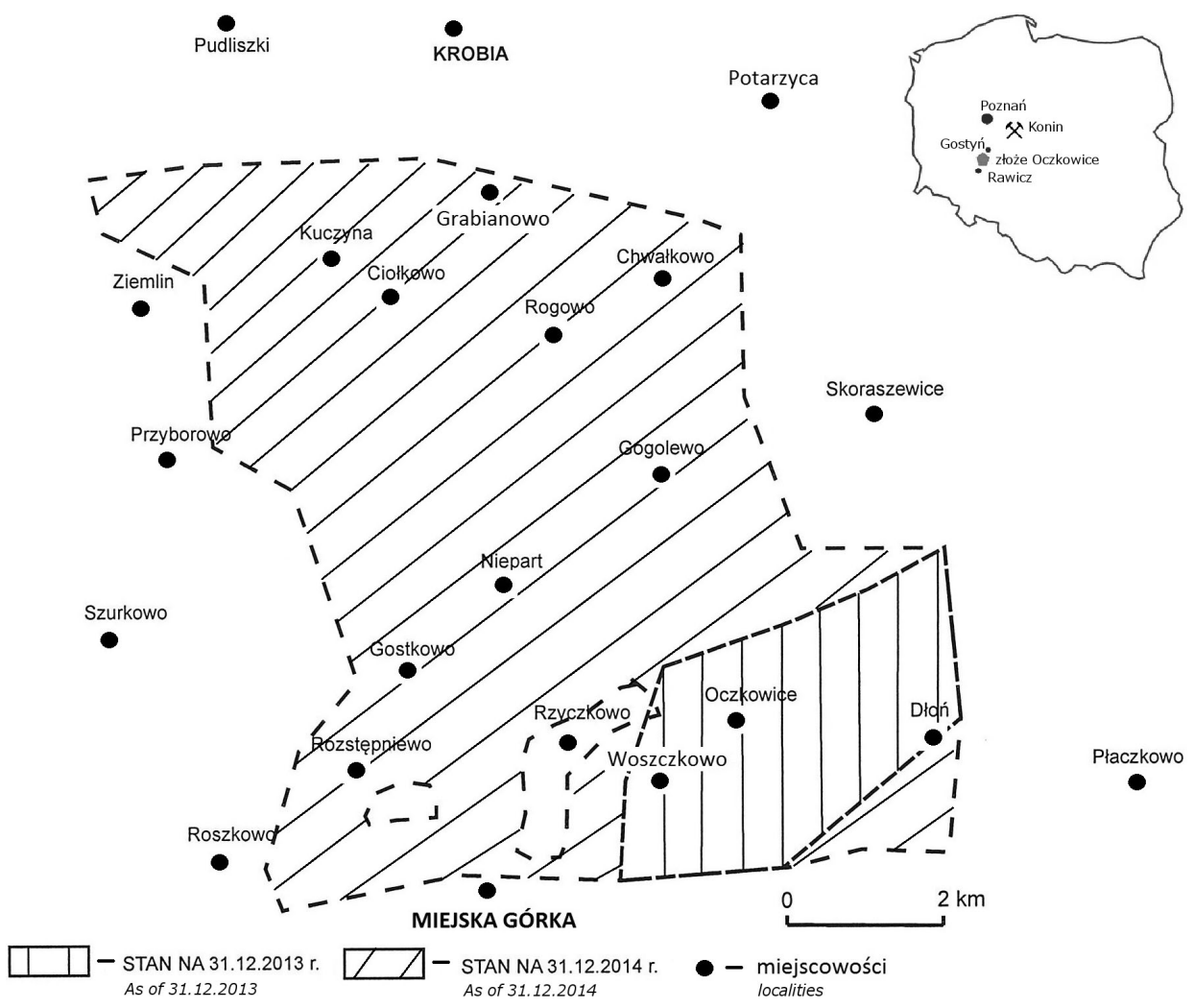

Ryc. 3. Złoża węgla brunatnego Oczkowice w południowo-zachodniej Wielkopolsce wg bazy MIDAS PIG-PIB The Oczkowice lignite deposit in south-western Wielkopolska (so-called Greater Poland) according to MIDAS PIG-PIB database

Źródło / Source: J. Przybyłek, J. Górski (2016).

Eksploatacja węgla brunatnego na terenie gminy Krobi spowoduje nieodwracalne zmiany środowiskowe, przestrzenne oraz społeczne:

- Przekształcenie około $90 \mathrm{~km}^{2}$ powierzchni terenu rolniczego i zniszczenie zwartej zabudowy, co najmniej 13 wsi na obszarze złoża i w zarysie skarp zewnętrznych wyrobiska górniczego. Nastąpi wysiedlenie ludności oraz likwidacja miejscowości położonych na obszarze złoża - 5800 osób przymusowo będzie musiała sprzedać swoje domy i działki.

- Gospodarstwa Stadniny Koni Pępowo w Gogolewie i Nieparcie o powierzchni około 1100 ha, które znajdują się na terenie planowanej kopalni, zostaną trwale utracone, co przy 130 metrowym wkopie w złożu Oczkowice sprawia, że użytki rolne znajdą się w bezpośrednim zasięgu leju depresyjnego (Poczta i in. 2014). 
- Konieczność przejęcia dalszych powierzchni gruntów rolnych pod budowę przyszłego kompleksu górniczo-energetycznego (zwałowisko, zakład górniczy i jego zaplecze, budowle energetyki cieplnej, drogi transportu surowca, itd.) spowoduje dezorganizację połączeń infrastrukturalnych (dróg, sieci energetycznych, wodociągowych, kanalizacyjnych, urządzeń melioracyjnych).

- Zdaniem W. Poczty i in. (2014) w ciągu 50 lat eksploatacji kopalni będzie wyłączone przeciętnie około $60 \%$ terenu gminy zajętej obecnie pod uprawę zbóż. W konsekwencji tego z bilansu zbóż w Polsce będzie ubywać średnio 11 tys. ton zboża, co będzie stanowiło ponad 0,5 mln ton o wartości około 0,4 mld zł. Gdy uwzględni się buraki cukrowe, rzepak, rośliny przemysłowe i inne oraz warzywa uprawiane dla zakładów HJH Polska SA w Pudliszkach i innych, to wartość niezrealizowanej produkcji będzie sięgać około $1 \mathrm{mld}$ zł.

- Trwała zmiana sposobu użytkowania terenu zajętego przez wyrobisko spowoduje zniszczenie wszystkich struktur hydrogeologicznych z niezwykle cennymi zbiorowiskami wód podziemnych dla gospodarki wodnej Wysoczyzny Kaliskiej, a także bardzo negatywne przekształcenia w systemach regionalnego krążenia wód podziemnych.

- Działalność kopalni pozbawi warsztatów pracy mieszkańców gminy, pojawi się bezrobocie. Nie łudźmy się, że wysiedleni rolnicy dostaną pracę w kopalni, bowiem pracować będą wykwalifikowani górnicy pochodzący z zamykanych kopalni zespołu Konin-Pątnów-Adamów.

Ważną sprawą jest również rekultywacja terenu pokopalnianego. Wg J. Wójcika i W. Krzaklewskiego (2010) przemysł wydobywczy w Polsce od 1945 r. zajął około 70 tys. ha powierzchni, głównie gruntów rolnych i leśnych. Z tego około 30 tys. ha zostało przekazane do zagospodarowania. W przypadku złoża Oczkowice należy spodziewać się, że tereny zrekultywowane nie będą stanowiły $90 \%$ użytków rolnych, a znacznie mniej, gdyż duża część zajętego terenu pod kopalnię będzie obejmować niezasypane wyrobisko, na którym będzie prawdopodobnie jezioro i stoki jeziora, które przeznaczone zostaną na tereny rekreacyjne lub leśne (Poczta i in. 2014). Według S. Gruszczyńskiego (2010) gleby urbanoziemne różnią się od gleb ukształtowanych naturalnie ubóstwem środków pokarmowych oraz niestabilnością plonowania. Stąd też jakość odzyskanych użytków rolnych pod względem przyrodniczym i gospodarczym przez wiele dziesiątków lat będzie wątpliwa i mało atrakcyjna dla rolników.

Od 2012 r. dla przedłużenia żywotności zagłębia konińskiego rozpoczęto działania dla poszerzenia bazy surowcowej tego zagłębia o eksploatację złoża Poniec-Krobia. Wywołało to olbrzymi rezonans społeczny w postaci masowych wystąpień i działań protestacyjnych, odnotowanych w prasie regionalnej i krajowej, a także założonych przez mieszkańców gminy stron: internetowej ${ }^{2}$ oraz na Facebooku³.

\footnotetext{
2 http://stopkopalni.pl/[dostęp: 15.01.2017].

3 https://www.facebook.com/STOPkopalni/[dostęp: 15.01.2017].
} 


\section{Podsumowanie}

Rozwój oparty na założeniach koncepcji zakorzenienia korzysta ze wspólnych zasobów, dóbr wywodzących się z lokalnej specyfiki endogenicznych surowców oraz umiejętności ich zagospodarowania. Te warunki spełnia gmina Krobia, bowiem wspólne zasoby związane z rolnictwem dostrzeżono pod koniec XIX w., doceniono i konsekwentnie dąży się do ich wykorzystania. Władza Krobi realizuje kolejne projekty rozwojowe w oparciu o lokalne zasoby, które są dobrze identyfikowane w regionie, gdyż obszar ten stanowi bezpieczeństwo żywnościowe dla województwa wielkopolskiego.

Pojawienie się wykorzystania zasobu lokalnego Krobi w postaci złoża węgla brunatnego stawia pytanie o utylitarność tych zasobów. Podjęcie decyzji o budowie głębokiej kopalni odkrywkowej spowoduje bezpowrotną utratę historycznych i rozwojowych walorów dotychczasowej przestrzeni, czyli niezwykle cennej sfery produkcyjnej rolnictwa w regionie (historycznie ukształtowana wysoka kultura rolna, ponadprzeciętna produkcja rolna oraz dobre klasy bonitacyjne gleb).

Eksploatacja węgla brunatnego jest już i będzie w najbliższej przyszłości przyczyną gwałtownych konfliktów społecznych, przestrzennych, środowiskowych i gospodarczych. Sukces badanego obszaru zależny jest od umiejętności wykorzystania posiadanych zasobów endogenicznych, dlatego zasadne i konieczne jest utrzymanie społecznie akceptowanej i wiodącej funkcji rolniczej gminy Krobia.

\section{Literatura}

Adamski T., Gorlach K., 2007, Koncepcja rozwoju neo-endogennego, czyli renesans znaczenia wiedzy lokalnej, [w:] K. Gorlach, M. Niezgoda, Z. Seręga (red.), Socjologia jako służba społeczna. Pamięci Władysława Kwaśniewicza, Wydawnictwo Uniwersytetu Jagielońskiego, Kraków, s. 137-150.

Agrochemiczne badania gleb Wielkopolski w latach 2000-2004, 2005, WIOŚ, Poznań.

Chojnicki Z., 1999, Podstawy metodologiczne i teoretyczne geografii, Bogucki Wydawnictwo Naukowe, Poznań.

Ciok E., 1963, Komunikat wstępny o odkryciu węgla brunatnego w otworze "Oczkowice nr 41.029.5" w Oczkowicach, pow. Rawicz, woj. Poznań, Baza MIDAS PIG PIB, Warszawa.

Dicken P., 2004, Geographers and 'globalization': (yet) another missed boat?, Transactions of the Institute of British Geographers, 29,1, s. 5-26.

Granovetter M., 1985, Economic action and social structure: The problem of embeddedness, American Journal of Sociology, 91, 3, s. 481-510.

Grzeszczak J., 1999, Bieguny wzrostu a formy przestrzeni spolaryzowanej, Prace Geograficzne 173, IGiPZ PAN, Warszawa.

Gruszczyński S., 2010, Klasyfikacja gleb rekultywowanych terenów pogórniczych, Przegląd Górniczy, 10, s. $120-125$.

Jasiński J., Michalska S., Śpiewak R., 2014, Rynki zakorzenione - koncepcja uruchomienia mechanizmów lokalnego rozwoju, Wieś i Rolnictwo, 3 (164), s. 105-123.

Kasztelewicz Z., Sikora M., Zajączkowski M., 2012, Złoże Poniec - Krobia w bilansie konińskiego zagłębia górniczo-energetycznego węgla brunatnego, Polityka Energetyczna 15, 3, s. 135-146.

Kondracki J., 2002, Geografia regionalna Polski, PWN, Warszawa. 
Kuźmiński A., 2012. Biskupizna ze smakiem. Przewodnik kulinarny po kuchni biskupiańskiej, Gmina Krobia.

Poczta W., Pepliński B., Bartkowiak N., 2014, Wpływ budowli kopalni odkrywkowej na sytuację produkcyjno-ekonomicznq rolnictwa i strukturę społeczno- kulturowq obszaru odkrywki. Strona internetowa: http://stopkopalni.pl/wp-content/uploads/2014/06/Ocena-skutk\%C3\%B3wbudowy-kopalni-odkrywkowej-dla-rolnictwa.pdf [dostęp: 1.06.2016].

Polanyi K., 1944. The great transformation: The political and economic origins of our time, Beacon Press, Boston.

Południowy Obszar Intensywnego Rolnictwa, 2014, Wielkopolskie Biuro Planowania Przestrzennego w Poznaniu.

Przybyłek J., 2015, Węgiel brunatny - bogactwo czy przekleństwo południowo-zachodniej Wielkopolski, Przegląd Wielkopolski 3 (109), s. 35-49.

Przybyłek J., Górski J., 2016. Złoże węgla brunatnego Oczkowice-głos za właściwym rozpoznaniem hydrologicznym, Przegląd Geologiczny, 64, 3, s. 183-191.

Stachowiak K., 2011, Rola koncepcji zakorzenienia w geograficznych badaniach nad globalizacja, Podstawowe Idee i Koncepcje w Geografii, 1, s. 83-99.

Strategia Rozwoju Gminy Krobia na lata 2014-2020, 2014, Rada Miejska w Krobi, Krobia.

Studium Uwarunkowań i Kierunków Zagospodarowania Przestrzennego Gminy Krobia, 2011, Rada Miejska w Krobi, Krobia.

Waloryzacja rolniczej przestrzeni produkcyjnej, 2007, Instytut Uprawy Nawożenia i Gleboznawstwa. Puławy.

Wójcik J., Krzaklewski W., 2010, Metody rekultywacji leśnej terenów bezglebowych w górnictwie odkrywkowym, Przegląd Górniczy, 10, s. 115-199.

\section{Summary}

A factor of commune's development is the activation of its internal potential as determined by possessed resources. Local resources can be material in nature (raw materials, products, environmental assets) and non-material (relations, skills and abilities, links, culture). They can be stimulants of local development based on the concept of embeddedness. In this context were presented conditions and resources of a typically agricultural commune of Krobia, situated in the south-western part of the Wielkopolskie Voivodeship, that contribute to its local and regional development. Krobia commune is also an area where potentially workable beds of brown coal (lignite) occur. Its resources are well documented (the Poniec- Krobia deposit). The establishment of an open-pit mine here will have many adverse effects for the very well developed agriculture, and in consequence for the local community. On the basis of an assessment for usability of resources and their role in local and regional development, the commune's embeddedness should be strengthened, so the added value derived from inhabitants' farming activity would be to the highest extent used in the commune and serve its further development. 


\section{Informacja dla Autorów}

Studia Obszarów Wiejskich to wydawnictwo publikujące oryginalne opracowania naukowe z zakresu geografii społeczno-ekonomicznej, geografii wsi i przestrzennego zagospodarowania kraju w języku polskim lub/i angielskim. Zapraszamy Autorów do nadsyłania wartościowych artykułów. Przestrzeganie poniższych zaleceń formalnych usprawni prace redakcyjne i przyczyni się do szybszej publikacji nadsyłanych materiałów.

Uwagi ogólne. Zgłoszenie przez autora (ów) tekstu do Studiów Obszarów Wiejskich oznacza, że nie jest on przewidziany do druku w innym wydawnictwie. Jest także jednoznaczne z wyrażeniem zgody na jego rozpowszechnianie przez IGiPZ PAN w formie drukowanej i elektronicznej z wykorzystaniem licencji Creative Commons: uznanie autorstwa, 3.0 Polska.

Podstawowym sposobem przekazania materiałów do druku jest przesłanie tekstu i załączników na płycie CD na adres wskazany przez redakcję. Tekst artykułu powinien być napisany zwięźle, ale jasno, przy użyciu edytora MS WORD. Objętość artykułu nie powinna przekraczać 6000 słów. Wszystkie załączniki graficzne muszą być dostarczone w formie osobnych plików. Preferowany format dla danych liczbowych to MS EXCEL, a dla załączników graficznych pliki w formacie JPG, TIF, EPS, CDR*, AL* (*Wymagany zapis do edycji w starszych wersjach programów, na chwilę obecną: Corel Draw do wersji 14, Adobe llustrator do wersji 11).

Strona tytułowa. Na pierwszej stronie należy w kolejności umieścić: tytuł pracy w języku polskim, tytuł pracy w języku angielskim, imię i nazwisko autora/autorów (cyfry arabskie po nazwisku, umieszczane jako indeks górny, określają odp. afiliację), afiliację, adres (y), e-mail (e), zarys treści (maksymalnie 200 słów powinien zawierać: sformułowanie celu pracy/badań, identyfikację obiektu badań, przedmiotu rozważań, istotę stosowanej metody, najważniejsze wyniki i wnioski), słowa kluczowe (podaje się nie więcej niż 5 słów kluczowych).

Tekst artykułu pisany czcionką Calibri Light 10, interlinia 1,0. Nie należy nadawać odrębnych stylów znakowych i akapitowych oraz specyficznych wyróżnień (kolor, podkreślenia, itd.) fragmentom tekstu. W tekście opracowania, przy powoływaniu się na literaturę, należy podawać nazwisko autora oraz rok publikacji, np. (Nowak 2004; Kowalski 2005, 2007) lub według A. Nowaka (2006), a przy cytowaniu również numer strony, np. według A. Nowaka (2006, s. 6). W powołaniach na więcej prac tego samego autora, które ukazały się w tym samym roku, podaje się: (Nowak 1987a, b). W przypadku wspólnej publikacji dwóch autorów podaje się: (Kowalski i Nowak 1999), a trzech i więcej autorów: (Kowalski i in. 2006).

Podziękowania - opcjonalnie oraz ewentualna informacja o źródłach finansowania publikacji i wkładzie innych podmiotów w opracowanie publikacji (zgodnie z wymogami jakościowymi i standardami etycznymi opisanymi niżej) należy zamieścić po zasadniczym tekście.

Rysunki i fotografie z podpisami i objaśnieniami w j. polskim i angielskim powinny być zamieszczone w tekście, a ponadto dołączone w postaci osobnych plików posiadających numerację zastosowaną w tekście. Wymagana jest wysoka rozdzielczość rysunków i fotografii (min. 300 dpi w plikach rastrowych JPG lub TIF). Dopuszczalne formaty wektorowe (EPS, Al*, CDR*). Tytuł ryciny i źródło w języku polskim i angielskim powinny znajdować się poza rysunkiem, w pliku tekstowym. Objaśnienia znaków legendy w języku polskim i angielskim można zamieścić w obrębie ryciny lub poza nią. Rysunki i fotografie drukowane są w kolorze czarno-białym. Należy upewnić się, że po zastąpieniu ew. kolorów skalą szarości i przeskalowaniu do rozmiarów maksymalnie 12,5 x $20 \mathrm{~cm}$ będą one wystarczająco czytelne. Zalecany krój czcionki dla napisów będących częścią grafiki (bez możliwości edycji) to Calibri.

Tabele powinny być zamieszczone w tekście. Każda tabela powinna zawierać zwięzły tytuł (u góry) w języku polskim, kolejny numer i źródło danych (u dołu). Wszystkie skróty powinny być objaśnione (tytuł, źródło i objaśnienia należy dołączyć jedynie w pliku tekstowym). W komórkach tabeli nie powinny znajdować się znaki tabulacji (Tab) ani końca akapitu (Enter) - w razie potrzeby można korzystać ze znaku wymuszonego końca wiersza (Shift+Enter). Należy unikać nietypowego formatowania (jak wypełnienia kolorystyczne komórek, różne grubości linii, itd.).

Spis literatury ograniczony do literatury cytowanej, w porządku alfabetycznym, należy zamieścić poniżej tekstu artykułu według poniższego wzoru:

Artykuły w czasopismach i seriach wydawniczych:

Wójcik M., 2011, Współczesne kierunki i podejścia badawcze w geografii wsi, Przegląd Geograficzny, 83, 2, s. $163-185$.

Kulikowski R., 2013, Obszary wiejskie województwa podlaskiego w perspektywie 2050 roku, Studia Obszarów Wiejskich, 31, s. 129-142.

Rozdziały w pracach zbiorowych:

Zegar J.S., 2014, Typy społeczno-ekonomiczne indywidualnych gospodarstw rolnych według rodzaju gmin, [w:] R. Rudnicki. M. Kluba (red.), Zintegrowany rozwój obszarów wiejskich w świetle polityki Unii Europejskiej, t. 1, Rolnictwo i Wspólna Polityka Rolna, Wydawnictwo Naukowe Uniwersytetu Mikołaja Kopernika, Toruń, s. $57-73$.

Książki

Bański J., 2006, Geografia polskiej wsi, PWE, Warszawa. 
Streszczenie. Na końcu opracowania powinno być zamieszczone streszczenie w języku angielskim zweryfikowane przez native-speakera. Objętość streszczenia: około 250-400 słów.

Ocena artykułów i dopuszczenie ich do druku. Wszystkie artykuły niespełniające powyższych zasad będą odsyłane do poprawy. Artykuły podlegają ocenie przez dwóch recenzentów. W procesie recenzowania stosowane jest rozwiązanie, w którym autor (zy) i recenzenci nie znają swoich tożsamości (tzw. „double-blind review proces").Wynik recenzji będzie miał decydujący wpływ na możliwość opublikowania materiału w Studiach Obszarów Wiejskich.

Zasady dotyczące recenzowania w Studiach Obszarów Wiejskich

1. Do oceny każdej publikacji powołuje się co najmniej dwóch niezależnych recenzentów spoza jednostki, w której afiliowani są autorzy publikacji.

2. W przypadku tekstów powstałych w języku obcym, co najmniej jeden z recenzentów jest afiliowany w instytucji zagranicznej innej niż narodowość autora pracy.

3. W procesie recenzowania stosowane jest rozwiązanie, w którym Autor (zy) i recenzenci nie znają swoich tożsamości (tzw. double-blind review proces).

4. Wyznaczając recenzentów redakcja wydawnictwa zachowuje ponadto zasadę zapobiegania konfliktom interesów między recenzentem a autorem.

5. Recenzje mają formę pisemną i kończą się jednoznacznym wnioskiem do dopuszczenia artykułu do publikacji lub jego odrzucenia, względnie warunkowego dopuszczenia tekstu do publikacji po jego poprawieniu przez autora według uwag zawartych w recenzji. W takiej sytuacji recenzent może zastrzec sobie prawo do ponownego zrecenzowania pracy, po dokonaniu przez autora poprawek wskazanych w pierwszej recenzji. Do publikacji dopuszczane będą prace posiadające dwie pozytywne recenzje (zawierające wniosek o dopuszczenie do publikacji) - wzór recenzji poniżej.

6. Zasady kwalifikowania lub odrzucenia publikacji oraz formularz recenzji są podane do publicznej wiadomości na stronie internetowej wydawnictwa.

7. Nazwiska recenzentów nie są publikowane przy poszczególnych artykułach

Studia Obszarów Wiejskich

ARKUSZ RECENZII

Tytuł recenzowanego artykułu ......

1. Czy zagadnienie przedstawione w artykule jest istotne pod względem naukowym i może zainteresować szersze grono czytelników? Czy praca przedstawia oryginalne materiały autorskie, stanowi syntezę czy przegląd badań?

2. Czy tematyka artykułu odpowiada tematyce tomu i profilowi Studiów Obszarów Wiejskich?

3. Czy sposób przedstawienia tematu jest prawidłowy, to znaczy (odpowiedź: Tak lub Nie)

- czy tytuł dokładnie odpowiada treści?

- czy zagadnienie zostało przedstawione w sposób logiczny?

- czy wnioski wynikają z treści pracy?

- czy odpowiednie pozycje literatury zostały uwzględnione?

- czy ilustracje (tabele wykresy, mapy) są czytelne i wystarczające

4. Sugerowane poprawki (rozwinięcie na odwrotnej lub osobnej stronie). Drobne poprawki mogą być zaznaczone w tekście artykułu.

\section{WNIOSEK:}

Ocena artykułu:

Bardzo dobra

$\square$ Dobra

口 Przeciętna

口 Temat interesujący, ale słabo przedstawiony

Artykuł warto opublikować (właściwe podkreślić):

- w wersji przedstawionej przez autora (-ów)

- z ewentualnymi drobnymi poprawkami sugerowanymi przez recenzentów i/lub redakcję

- po dokonaniu zasadniczych zmian sugerowanych przez recenzentów i redakcję

- artykuł nie nadaje się do publikacji

Wymogi jakościowe i standardy etyczne. W trosce o dochowanie najwyższych standardów redakcyjnych oraz w celu zapobieżenia nierzetelności w publikacjach naukowych określanych jako tzw. ghostwriting i guest authorship Redakcja Studiów Obszarów Wiejskich wymaga od autorów ujawniania informacji o podmiotach przyczyniających się do powstania publikacji (wkład merytoryczny, rzeczowy, finansowy etc.). W tym celu zobowiązuje się autorów do zachowania następujących standardów podczas przygotowywania tekstów składanych do publikacji: 1) w przypadku publikacji naukowych, które nie zostały wykonane samodzielnie, tzn. opracowano je we współautorstwie lub z wykorzystaniem pomocy wyspecjalizowanego podmiotu (osoby fizycznej lub praw- 
nej), w końcowej części pracy (w punkcie: „Podziękowania”) należy zawrzeć notę, w której ujawniany jest wkład poszczególnych autorów (współautorów) w powstanie publikacji (artykułu, monografii). Oznacza to konieczność podania ich afiliacji oraz kontrybucji, tj. informacji kto jest autorem koncepcji, założeń, zastosowanych metod, protokołu itp., wykorzystywanych w toku pracy badawczej - przygotowywania publikacji; główną odpowiedzialność ponosi autor zgłaszający manuskrypt. 2) Autor/współautorzy podają ponadto informację o ewentualnych źródłach finansowania publikacji, wkładzie instytucji naukowo-badawczych, stowarzyszeń i innych podmiotów w opracowanie publikacji (financial disclosure). Redakcja wydawnictwa informuje, że wszelkie przejawy nierzetelności naukowej, zwłaszcza łamania i naruszania zasad etyki obowiązujących w nauce, w tym wykryte przypadki ghostwriting, guestauthorship będą dokumentowane i oficjalnie demaskowane, włącznie z powiadomieniem odpowiednich podmiotów (instytucje zatrudniające autorów, towarzystwa naukowe, stowarzyszenia edytorów naukowych itp.).

Z ghostwriting mamy do czynienia wówczas, gdy ktoś wniósł istotny wkład w powstanie publikacji, bez ujawniania swojego udziału jako jeden z autorów lub bez wymieniania jego roli w Podziękowaniach zamieszczonych w publikacji.

Z guest authorship (honorary autorship) mamy do czynienia wówczas, gdy udział autora jest znikomy lub w ogóle nie miał miejsca, a pomimo to jest autorem/wspłautorem publikacji.

Wersja pierwotna. Wersja papierowa i elektroniczna są tożsame, jednakże Redakcja wskazuje wersję papierową jako wersję pierwotną czasopisma.

\section{Adres Redakcji}

ul. Twarda 51/55, 00-818 Warszawa

tel. (+48 22) 69788 34, fax (+48 22) 6206221

e-mail: b.solon@twarda.pan.pl

Redaktor Naczelny Studiów Obszarów Wiejskich 


\section{Recenzenci / Reviewers 2016}

Redakcja wyraża serdeczne podziękowanie wszystkim Recenzentom za ich trud, zaangażowanie i wiedzę włożone w trakcie recenzowania artykułów przysłanych do czasopisma Studia Obszarów Wiejskich / Rural Studies.

The Editors would like to extend their deepest thanks to all the Reviewers for their special effort, commitment and invaluable contribution in reviewing the papers submitted to Studia Obszarów Wiejskich / Rural Studies.

Maria BEDNAREK-SZCZEPAŃSKA (Institute of Geography and Spatial Organization PAS)

Mirosław BICZKOWSKI (Nikolaus Copernicus University in Toruń)

Henryk BRANDENBURG (University of Economics in Katowice)

Denis CERIĆ (Institute of Geography and Spatial Organization PAS)

Paweł CHMIELIŃSKI (Institute of Agricultural and Food Economics - National Research Institute)

Konrad CZAPIEWSKI (Institute of Geography and Spatial Organization PAS)

Jarosław DOMALEWSKI (Nikolaus Copernicus University in Toruń)

Wiesław DROBEK (Opole University of Technology)

Małgorzata DURYDIWKA (University of Warsaw)

Małgorzata FLAGA (Maria Curie Skłodowska University)

Krzysztof JANC (University of Wrocław)

Wojciech JANICKI (Maria Curie Skłodowska University)

Anna JASIŃSKA-BILICZAK (Opole University of Technology)

Pamela JEZIORSKA-BIEL (University of Łódź)

Ewa KACPRZAK (Adam Mickiewicz University in Poznań)

Wioletta KAMIŃSKA (Jan Kochanowski University)

Wojciech KNIEĆ (Nikolaus Copernicus University in Toruń)

Wiesław KOCZUR (University of Economics in Katowice)

Roman KULIKOWSKI (Institute of Geography and Spatial Organization PAS)

Barbara MAĆKIEWICZ (Adam Mickiewicz University in Poznań)

Tomasz MICHALSKI (University of Gdansk)

Urszula MYGA-PIĄTEK (University of Silesia in Katowice)

Lucyna PRZYBYLSKA (University of Gdansk)

Diana ROKITA-POSKART (Opole University of Technology)

Brygida SOLGA (Opole University of Technology)

Jerzy SOLON (Institute of Geography and Spatial Organization PAS)

Monika STANNY (Institute of Rural and Agricultural Development PAS)

Sylwia STASZEWSKA (Adam Mickiewicz University in Poznań)

Marzena SZEWCZUK-STĘPIEŃ (Opole University of Technology)

Mirosława SZEWCZYK (Opole University of Technology)

Kazimierz SZCZYGIELSKI (Opole University of Technology)

Wioletta SZYMAŃSKA (Pomeranian University in Słupsk)

Małgorzata TWARDZIK (University of Economics in Katowice)

Krzysztof WASIELEWSKI (Nikolaus Copernicus University in Toruń)

Marcin WÓJCIK (University of Łódź)

Alicja ZAKRZEWSKA-PÓŁTORAK (Wrocław University of Economics) 